\title{
EVALUATION OF THE BARRIER POTENTIAL OF SOME SYNTHETIC MEMBRANES IN TESTING THE IN VITRO TENOXICAM RELEASE FROM HYDROGELS, USING THE EXPERIMENTAL MODEL WITH FRANZ DIFFUSION CELLS
}

\author{
IOANA OLARIU ${ }^{1 \#}$, GEORGETA CONEAC ${ }^{1 \#}$, MIRCEA HÎRJĂU ${ }^{2}$, CĂLIN POPOIU ${ }^{3 *}$, ANA \\ MARIA MUȚ ${ }^{1}$, VICENŢIU VLAIA ${ }^{1}$, ANI-SIMONA SEVASTRE ${ }^{4}$, DUMITRU LUPULIASA ${ }^{2}$, \\ LAVINIA VLAIA ${ }^{1}$ \\ ', Victor Babeș” University of Medicine and Pharmacy, Faculty of Pharmacy, Eftimie Murgu Square no. 2, 300041, Timişoara, \\ Romania \\ ${ }_{2}^{2}$,Carol Davila” University of Medicine and Pharmacy, Faculty of Pharmacy, Traian Vuia Street no. 6, Bucharest, Romania \\ ", "Victor Babeş" University of Medicine and Pharmacy, Faculty of Medicine, Eftimie Murgu Square no. 2, 300041, Timişoara, Romania \\ ${ }^{4}$ University of Medicine and Pharmacy, Faculty of Pharmacy, Petru Rareş Street no. 2-4, Craiova, Romania
}

*corresponding author: mcpopoiu@umft.ro

${ }^{*}$ Authors with equal contribution

Manuscript received: June 2018

\begin{abstract}
The present study aimed to investigate the suitability of some porous synthetic membranes as limiting barrier for testing the in vitro tenoxicam release from topical hydrogels. Two cellulose esters-based membranes and three polymeric membranes (polyamide, polyethersulfone and polysulfone) possessing the same pores diameter $(0.45 \mu \mathrm{m})$ but different thickness and porosity were tested. The permeability assessment of these synthetic membranes was performed using a system of six Franz diffusion cells accompanied by UV spectrophotometric analysis. Two HPMC-based hydrogel formulations containing tenoxicam either dissolved or suspended in the respective systems were used to evaluate the impact of drug dispersed form on the synthetic membranes resistance on its in vitro diffusion. The results of the in vitro tenoxicam release studies suggested that the tested synthetic membranes behaved either as high-flux or low-flux membranes, whose permeability to tenoxicam depended both on their physical characteristics (especially porosity and tortuosity) and on the dispersed form of TNX in the hydrogels. The overall results suggest that the microfiltration membranes (polyethersulfone and polysulfone), possessing a porosity of over $60 \%$ and a maximal thickness of $150 \mu \mathrm{m}$ should be the first choice of membrane to be used with Franz diffusion cells for the in vitro performance assessment of topical hydrogels containing tenoxicam.
\end{abstract}

\section{Rezumat}

Scopul prezentului studiu a fost investigarea potențialului unor membrane sintetice poroase ca barieră limitantă pentru testarea eliberării in vitro a tenoxicamului din hidrogeluri topice. Au fost testate două membrane pe bază de esteri de celuloză şi trei membrane polimerice (poliamidă, polietersulfonă și polisulfonă). Evaluarea permeabilității acestor membrane sintetice a fost efectuată folosind un sistem de şase celule de difuzie Franz și analiza spectrofotometrică în UV. Două formulări de hidrogeluri pe bază de HPMC conținând tenoxicam dizolvat sau suspendat au fost utilizate pentru a evalua impactul modului de dispersare a substanței medicamentoase asupra rezistenței membranelor sintetice la difuzia acesteia in vitro. Rezultatele studiilor de eliberare in vitro a tenoxicamului au sugerat că membranele sintetice testate s-au comportat ca membrane de mare flux sau de mic flux, a căror permeabilitate față de tenoxicam a fost dependentă atât de caracteristicile lor fizice (în special porozitatea și tortuozitatea) cât și de modul de dispersare a tenoxicamului în hidrogeluri. Toate rezultatele studiului sugerează faptul că membranele de microfiltrare (polietersulfonă și polisulfonă), având o porozitate de peste $60 \%$ și o grosime de cel mult $150 \mu \mathrm{m}$ pot fi de primă alegere pentru a fi utilizate cu celule de difuzie Franz pentru testarea in vitro a performanței hidrogelurilor topice cu tenoxicam.

Keywords: synthetic membranes, in vitro drug release, tenoxicam, topical hydrogels

\section{Introduction}

Nowadays, it is well known that the drug release from dermal dosage forms has a great influence on their therapeutic efficacy, therefore several assay methods have been proposed and tested. Among these, the in vitro drug release test using Franz diffusion cells and biological or synthetic membranes is the most commonly used method especially for the development and screening studies of new topical formulations, but also for the in vivo prediction of drug percutaneous permeation $[2,11,15,16]$. This method is generally accepted because it is simple, cost efficient and permits to adapt the experimental conditions to the purpose of 
FARMACIA, 2019, Vol. 67, 1

the study [17]. The human and animal skin as biological model membranes mimic in the highest manner the in vivo human skin, but their use is limited by several important inconveniences like: high variability (source, preparation, storage conditions) which entails complications in the design of experiments and a low data reproducibility; short half-life, special preservation and preparation conditions, safety issues; high cost and reduced availability (human skin) and ethical issues (animal skin) $[1,6,12,13]$. Based on the abovementioned drawbacks, the biological membrane models are considered now unsuitable for the performance evaluation of the topical product (as part of its quality control). For this purpose and for skin simulation, the synthetic membranes are considered a better alternative [2,3], as they offer several advantages, such as: controlled dimensional properties (pore sizes or molecular weight cut-off and thickness); high chemical, thermal and mechanical stability; biological inertia; relatively low cost; easy handling and preparation during the experiments; no special requirements for storage [4, 8].

Usually, silicone-based synthetic membranes (polydimethylsiloxane and polydimethylsiloxanepolycarbonate block copolymer) are used for imitating the skin, because they are hydrophobic and have similar rate limiting properties like the corneous layer [8]. Instead, the artificial membranes used for the performance test of the topical product must exhibit minimal diffusion resistance to the drug and act only as a support, separating the preparation from the acceptor medium [16]. Therefore, the majority of the synthetic membranes used with Franz cells in the in vitro release studies are porous membranes with different porosity and thickness, designed for other applications, namely separation and filtration (microfiltration and ultrafiltration) and are composed of semi-synthetic or synthetic polymers $[1,7]$. The FDA and recently the United States Pharmacopoeia recommend simple porous synthetic membranes (e.g. cellulose acetate or nitrate, polysulfone) as being suitable for performance evaluation of topical preparations, as they act as a support without being a limiting barrier for the release rate $[2,18]$. However, recent studies have highlighted that different types of porous synthetic membranes oppose resistance and can simultaneously act as limiting rate barriers $[8$, 9]. Therefore, researchers are motivated to select the appropriate membranes for testing the drug release/permeation from a topical formulation.

The purpose of this study was to evaluate the barrier capacity of five commercial synthetic membranes in the in vitro availability of tenoxicam (TNX) from hydroxypropylmethylcellulose (HPMC) hydrogels. The model drug used in this study, TNX, is a hydrophobic, very slightly watersoluble compound (MW 337.21, $\log$ P 1.9 and pKa 2.21). TNX was dissolved or suspended in the hydrogel base.

\section{Materials and Methods}

\section{Materials}

Tenoxicam was generously donated by SC "Laropharm" S.R.L. Romania. Hydroxypropylmethylcellulose (Methocel K4M) was obtained as a free sample from Colorcon L.t.d. (England), and polyethylene glycol 600 (PEG 600) was donated by BASF Chem Trade GmbH (Germany). Ethanol $(96 \% \mathrm{w} / \mathrm{v})$, sodium chloride, sodium hydroxide, disodium phosphate and monopotassium phosphate were purchased from S.C. Chemical Company S.A. (Romania), and methyl p-hydroxybenzoate and propyl p-hydroxybenzoate were supplied by Stera Chemicals (Romania). Distilled water was used to prepare the hydrogels, and bidistilled water was used to prepare phosphate buffered saline $\mathrm{pH}$ 7.4. All these materials were used as such, being of analytical or pharmaceutical purity.

In Table I are presented the synthetic membranes used in this study for the in vitro diffusion experiments with vertical diffusion cells. Table I also shows the manufacturer and describes the characteristics of each type of membrane: thickness, pore diameter, porosity $(\rho)$ and tortuosity $(\tau)$. All the membranes on the list are porous, as the present study was focused only on the membranes used in the quality control of topical products.

Table I

Brief presentation of the properties of the synthetic membranes used in the experimental study. The values of the respective parameters are provided by the manufacturers

\begin{tabular}{c|c|c|c|c|c|c|c|c}
\hline Membrane & Polymer* & $\begin{array}{c}\text { Pores } \\
\text { diameter } \\
(\boldsymbol{\mu m})\end{array}$ & $\begin{array}{c}\text { Thickness } \\
(\boldsymbol{\mu m})\end{array}$ & $\begin{array}{c}\boldsymbol{\rho} \\
\mathbf{( \% )}\end{array}$ & $\boldsymbol{\tau}$ & Manufacturer & Batch \\
\hline \multicolumn{7}{c}{ Cellulose based membranes } \\
\hline $\begin{array}{c}\text { Teknokroma } \\
\text { TR-200240 }\end{array}$ & M.E.C & 0.45 & 150 & nd & nd & $\begin{array}{c}\text { Teknokroma } \\
\text { (Spania) }\end{array}$ & 133895 \\
\hline $\begin{array}{c}\text { Millipore } \\
\text { HAWG04700 }\end{array}$ & M.E.C & 0.45 & 180 & 79 & - & $\begin{array}{c}\text { Millipore } \\
\text { (Irlanda) }\end{array}$ & $\begin{array}{c}\text { R 5 CM6 } \\
2646\end{array}$ \\
\hline
\end{tabular}


FARMACIA, 2019, Vol. 67, 1

\begin{tabular}{|c|c|c|c|c|c|c|c|}
\hline Membrane & Polymer* & $\begin{array}{c}\text { Pores } \\
\text { diameter } \\
(\mu \mathrm{m}) \\
\end{array}$ & $\begin{array}{c}\text { Thickness } \\
(\mu \mathrm{m})\end{array}$ & $\begin{array}{c}\rho \\
(\%)\end{array}$ & $\tau$ & Manufacturer & Batch \\
\hline \multicolumn{8}{|c|}{ Polymeric membranes } \\
\hline $\begin{array}{c}\text { Teknokroma } \\
\text { TR-200120 } \\
\end{array}$ & $\mathrm{PA}$ & 0.45 & 150 & nd & $\overline{\text { nd }}$ & $\begin{array}{c}\text { Teknokroma } \\
\text { (Spania) }\end{array}$ & 123781 \\
\hline Supor & PES & 0.45 & 145 & 75 & $1-1.5$ & Pall (SUA) & T03552 \\
\hline Tuffryn & PS & 0.45 & 145 & 80 & $1-1.5$ & Pall (SUA) & T23321 \\
\hline
\end{tabular}

* M.E.C - blend of cellulose esters (nitrate and acetate), PA - polyamide (nylon), PES - polyethersulfone, PS - polysulfone

\section{Methods \\ Formulation and preparation of the 1\% tenoxicam hydrogels}

TNX was incorporated either by dissolution or by suspension in a HPMC-based hydrogel. The hydrogel base was prepared by dispersing HPMC in the amount of distilled water contained in the formulation, using the "hot/cold" method recommended by the manufacturer [19].

The preparation steps of the medicated hydrogel, containing dissolved tenoxicam (formulation GELTNXdiss) were as follows: 1) the dissolution of parabens (methyl parahydroxybenzoate and propyl parahydroxybenzoate in a mass ratio of 3:1) in the mixture of ethanol and PEG 600;2) the dispersion of tenoxicam in the parabens solution; 3) the complete dissolution of tenoxicam in the parabens solution by adding dropwise and under stirring a solution of $10 \%$ sodium hydroxide to neutral $\mathrm{pH} ; 4$ ) the addition of the tenoxicam solution to the HPMC-based hydrogel, followed by stirring until homogeneous.

The hydrogel containing suspended tenoxicam (GEL-TNXsusp formulation) was prepared by dissolving the parabens in the ethanol and PEG 600 mixture, then in the obtained solution the tenoxicam was dispersed. Over the resulting dispersion, the previously prepared HPMC hydrogel was added under stirring.

The concentrations of the components $(\% \mathrm{~m} / \mathrm{m})$ in the final preparations were: $1 \%$ tenoxicam, $2.5 \%$ HPMC, 20\% ethanol, 10\% PEG 600 and $0.065 \%$ parabens mixture.

The preparations were kept at $5^{\circ} \mathrm{C}$ for 24 hours before testing.

In vitro drug release studies using a Franz cell system with synthetic membranes

In vitro diffusion experiments were performed in accordance with FDA SUPAC-SS recommendations $[2,18]$, using a system of 6 Franz diffusion cells (Microette-Hanson system, model 57-6AS9, U.S.A.), with a diffusion area of $1.767 \mathrm{~cm}^{2}$ and a volume of $6.5 \mathrm{~mL}$ for the receptor chamber. The receptor chamber of each diffusion cell was filled with saline phosphate buffer $(\mathrm{pH}$ 7.4) mixed with $30 \%$ ethanol, freshly prepared, heated and deaerated. Synthetic membranes were hydrated by immersion in the receptor medium for 30 minutes before use, then mounted between the donor and acceptor compartment of the Franz diffusion cell. Approximately $0.300 \mathrm{~g}$ of the sample was weighed into the dosing capsule of each diffusion cell, then it was applied to the surface of the membrane at the top of the diffusion cell. The diffusion cells were tightly closed by fastening the dosing capsule with a clamp, thereby preventing the evaporation of the vehicle and ensuring the integrity of the formulation throughout the study. Throughout the test, the system was maintained at $32 \pm 1{ }^{\circ} \mathrm{C}$ and the receptor medium was shaken continuously (600 $\mathrm{rpm}$ ) by means of a magnetic stirrer to avoid the effects of the diffusion layer. $0.5 \mathrm{~mL}$ of the receptor solution were automatically withdrawn at $30 \mathrm{~min}$, $1,2,3,4,5,6,7$, and 8 hours and replaced with a fresh receptor medium to maintain the volume constant $(65 \mathrm{~mL})$ and to ensure sink conditions throughout the test. The samples were analysed spectrophotometrically in UV (UV-VIS T70 + spectrophotometer with UVWIN5 soft, PG Instruments, England) at $360 \mathrm{~nm}$, corresponding to the maximum absorbance of TNX in saline phosphate buffer $(\mathrm{pH} 7.4)$ with $30 \%$ ethanol. The test was linear in the TNX concentration range of $2.40-24.0 \mu \mathrm{g} / \mathrm{mL}\left(\mathrm{y}=0.4071 \mathrm{x}-0.0104, \mathrm{R}^{2}=\right.$ 0.9996). Each TNX hydrogel formulation was tested in 6 replicates and the data were presented as mean $\pm \mathrm{SD}$.

Data analysis

The average cumulative amount of membranepermeated TNX $\left(\mu \mathrm{g} / \mathrm{cm}^{2}\right)$ was plotted against time $(t, \mathrm{~h})$. The drug permeation rate at steady state (steady state flux, $J_{s s}, \mu \mathrm{g} / \mathrm{cm}^{2} / \mathrm{h}$ ) and lag time $\left(t_{L}, \mathrm{~h}\right)$ were calculated from the slope and the $x$-axis intercept of the linear portion of the plots of the cumulative amount of the permeated drug versus time. The permeability coefficient $(K p, \mathrm{~cm} / \mathrm{h})$ was calculated by dividing the steady-state flux to the initial concentration of the active substance in the donor compartment.

The release rate values $(k)$ were calculated based on the slopes of the cumulative amount of the drug that permeated through the membrane $\left(\mu \mathrm{g} / \mathrm{cm}^{2}\right)$ versus the square root of time. The diffusion coefficient values $(D)$ were calculated from the release rate values. 
Student-t test was used for data statistical analysis (Statistica software version 7.0) and the significance level was set at $\mathrm{p}<0.05$.

Regression analysis of tenoxicam flux values with the characteristic parameters of the tested synthetic membranes

As can be observed from the Table I, among the membranes characteristic parameters provided by the manufacturers, only the membrane thickness varied from one membrane type to another. Consequently, the flux values were only compared and correlated with the values of this parameter. Linear regression analysis was used to describe the relationships between the two variables.

\section{Results and Discussion}

Formulation and preparation of the hydrogels containing $1 \%$ tenoxicam

In this study, the model drug (TNX) incorporated into the HPMC-based hydrogel vehicle existed in two forms: completely dissolved as sodium salt (the dissociated form), having a thermodynamic activity $<1$ because the concentration of this form in hydrogel is lower than its saturation concentration, as it is more water-soluble than acid TNX; in suspension, resulting in a drug-saturated system, in which the thermodynamic activity of the drug is 1 , favouring the diffusion, since this parameter is considered to be the real force governing the diffusion of the drug substance from the vehicle in the membrane $[5,10,14]$. In the case (b), the cosolvent mixture (ethanol-PEG 600 in a ratio of $2: 1)$ in $30 \%$ concentration does not possess the ability to maintain tenoxicam (the non-dissociated form) dissolved. It is worth noting, that in the pharmaceutical field, the formulation of saturated systems, which are thermodynamically unstable, is avoided, because of the tendency of the drug to recrystallize and therefore the systems become nonhomogeneous. However, the hydrogel with suspended TNX was used in this study for comparative purpose, to assess the influence of the dispersion degree of the poorly water-soluble drug on its diffusion through different synthetic membranes.

In vitro diffusion of tenoxicam from the experimental hydrogels through synthetic membranes

The cumulative amounts of TNX that permeated per membrane surface unit (expressed in $\mu \mathrm{g} / \mathrm{cm}^{2}$ ) from the GEL-TNXdiss and GEL-TNXsusp formulations, through the synthetic membranes, over an 8 hours period, were graphically plotted versus time (Figure 1). The values of the specific release (release rate, $k$, diffusion coefficient, D) and diffusion (steady-state flux, Jss, permeability coefficient, $K_{P}$ and lag time, $t_{L}$ ) parameters of TNX through synthetic membranes, as well as the total amounts of TNX which diffused after 8 hours, calculated from the experimental data, are listed in Table II.
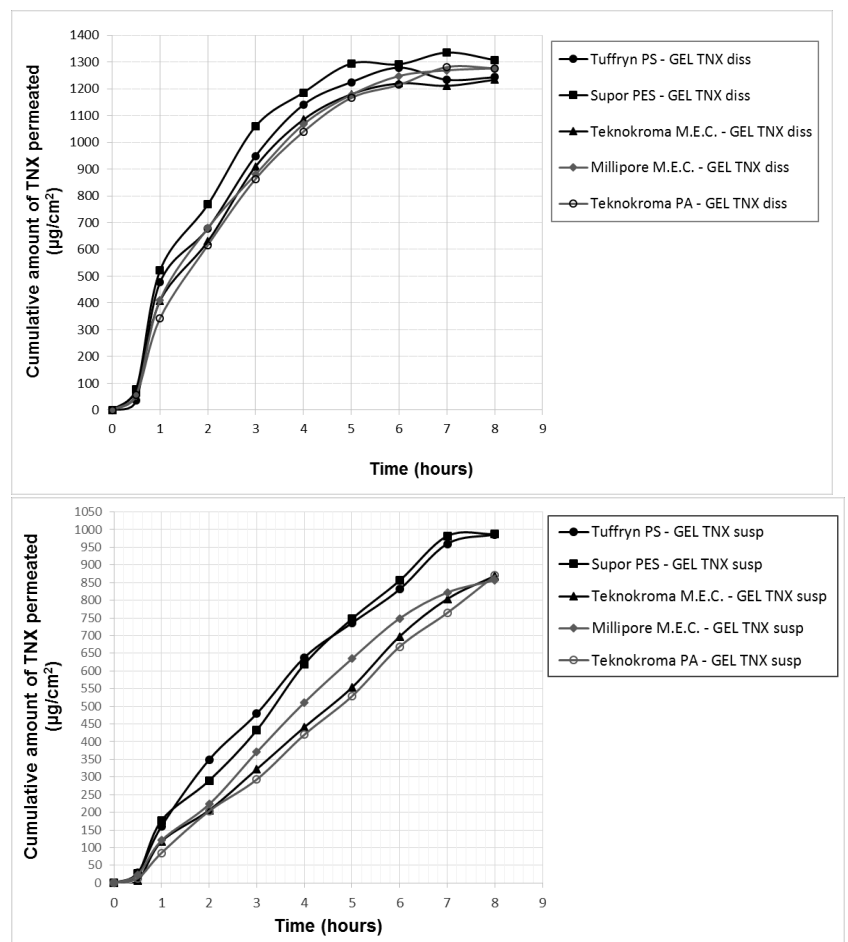

Figure 1.

The in vitro diffusion profiles of tenoxicam from the GEL-TNXdiss (A) and GEL-TNXsusp (B) formulations through different synthetic membranes 
Specific in vitro diffusion and release parameters of tenoxicam from the experimental hydrogels through various synthetic membranes

\begin{tabular}{|c|c|c|c|c|c|c|}
\hline Synthetic membrane & $\underset{\left(\mu \mathrm{g} / \mathrm{cm}^{2} / \mathrm{h}\right)}{J}$ & $\begin{array}{c}\mathrm{K}_{\mathrm{P}}(\mathbf{c m} / \mathbf{h}) \\
\times 10^{6}\end{array}$ & $\begin{array}{l}\mathbf{t}_{\mathrm{L}} \\
\text { (h) }\end{array}$ & $\begin{array}{l}\text { Total amount } \\
\text { of permeated } \\
\text { TNX }\left(\mu \mathrm{g} / \mathrm{cm}^{2}\right)\end{array}$ & $\begin{array}{c}\mathrm{k} \\
\left(\mu \mathrm{g} / \mathrm{cm}^{2} / \mathrm{h}^{1 / 2}\right)\end{array}$ & $\begin{array}{c}D\left(\mathrm{~cm}^{2} / \mathrm{h}\right) \\
\times 10^{3}\end{array}$ \\
\hline \multicolumn{7}{|c|}{ GEL-TNXdiss formulation } \\
\hline Tuffryn PS & $226.2 \pm 1.50$ & $226.2 \pm 1.50$ & - & $1279.06 \pm 0.31$ & $675.3 \pm 6.70$ & $3.579 \pm 0.91$ \\
\hline Supor PES & $228.7 \pm 1.15$ & $228.7 \pm 1.15$ & - & $1335.43 \pm 3.88$ & $689.6 \pm 0.72$ & $3.733 \pm 0.09$ \\
\hline Teknokroma M.E.C & $231.3 \pm 2.80$ & $231.3 \pm 2.80$ & - & $1233.77 \pm 1.59$ & $692.9 \pm 2.41$ & $3.765 \pm 0.28$ \\
\hline Millipore M.E.C & $216.9 \pm 1.23$ & $216.9 \pm 1.23$ & - & $1276.21 \pm 5.66$ & $652.9 \pm 3.59$ & $3.346 \pm 0.39$ \\
\hline Teknokroma PA & $233.9 \pm 4.01$ & $233.9 \pm 4.01$ & - & $1281.18 \pm 6.05$ & $704.3 \pm 2.85$ & $3.894 \pm 0.26$ \\
\hline \multicolumn{7}{|c|}{ GEL-TNXsusp formulation } \\
\hline Tuffryn PS & $129.2 \pm 4.75$ & $129.2 \pm 4.75$ & - & $986.30 \pm 2.87$ & $479.6 \pm 6.8$ & $1.826 \pm 0.85$ \\
\hline Supor PES & $137.9 \pm 2.45$ & $137.9 \pm 2.45$ & - & $987.37 \pm 4.07$ & $506.5 \pm 6.5$ & $2.013 \pm 0.77$ \\
\hline Teknokroma M.E.C & $116.9 \pm 3.51$ & $116.9 \pm 3.51$ & 0.161 & $869.34 \pm 1.28$ & $425.8 \pm 1.35$ & $1.423 \pm 0.02$ \\
\hline Millipore M.E.C & $129.0 \pm 0.77$ & $129.0 \pm 0.77$ & 0.133 & $856.79 \pm 4.46$ & $445.5 \pm 1.50$ & $1.558 \pm 0.04$ \\
\hline Teknokroma PA & $114.2 \pm 1.12$ & $114.2 \pm 1.12$ & 0.315 & $870.08 \pm 2.49$ & $484.7 \pm 4.46$ & $1.844 \pm 0.53$ \\
\hline
\end{tabular}

The curves of the cumulative amount of TNX diffused per membrane surface unit versus time from the GEL-TNXdiss formulation (Figure 1A) showed a linear portion, between 1 and 4 hours, for all the membranes used in the study. During this time, the flux and release rate of TNX dissolved in hydrogel through the nylon membrane (Teknokroma PA) showed the highest values, followed closely by those obtained for the diffusion through the membrane Teknokroma M.E.C (Table II). The drug transfer from the same hydrogel formulation (GEL-TNXdiss) through the Supor PES and Tuffryn PS membranes was slightly lower than that through the nylon membrane. The lowest flux and release rate values of TNX from the GELTNXdiss formulation were produced by Millipore M.E.C. It is noteworthy that, as expected, for the GEL-TNXdiss formulation no lag time was measured, the release and permeation of TNX for all the studied membranes has occurred from the beginning of the test.

Instead, the GEL-TNXsusp formulation released the drug through cellulose ether membranes (Teknokroma M.E.C. and Millipore M.E.C.) and Teknokroma PA membrane after a short lag time, of 0.13-0.31 hours (Table II), which highlights the unfavourable influence of the TNX dispersion type on its diffusion through the respective synthetic membranes. For the same reason, the TNX diffusion profiles from the hydrogel containing suspended drug through the studied synthetic membranes showed a linear segment between 1 and 6 to 7 hours (Figure 1B), and the steady-state flux and release rate values were 1.65 - 2 times, respectively, 1.36 - 1.62 times lower than those produced by the GEL-TNXdiss formulation (Table II). Furthermore, it was observed that the differences between the flux values through the tested membranes from the GEL-TNXsusp formulation were higher than those produced by the GEL-TNXdiss formulation. Based on the flux and release rates of TNX from the GEL-TNXsusp formulation, the permeability of the membranes used with the vertical diffusion cells can be hierarchized as follows: Supor PES membrane > Tuffryn PS membrane $=$ Millipore M.E.C. membrane > Teknokroma M.E.C membrane > Teknokroma PA membrane.

Comparing the total amount of TNX released from the two HPMC-based hydrogels through the tested artificial membranes after 6,7 or 8 hours, it was found that the highest amounts of drug were released from the GEL-TNXdiss formulation across all membrane types (Table II) with several differences. More precisely, the Supor PES membrane allowed the release of the largest amount of drug, followed closely by the Tuffryn PS, Millipore M.E.C and Teknokroma PA membranes, but the Teknokroma M.E.C membrane based on cellulose ethers allowed the release of a slightly lower amount of drug. In the case of the hydrogel containing suspended TNX, the most permeable for the drug were the Tuffryn PS and Supor PES membranes $(986.30 \pm 2.87$ and respectively 987.37 $\pm 4.07 \mu \mathrm{g} / \mathrm{cm}^{2} \mathrm{TNX}$ released), while the Teknokroma M.E.C, Teknokroma PA şi Millipore M.E.C membranes showed a lower permeability for TNX $\left(856.79 \pm 4.46-870.08 \pm 2.49 \mu \mathrm{g} / \mathrm{cm}^{2} \mathrm{TNX}\right.$ diffused $)$. In the experiments with Franz diffusion cells conducted in this study, the synthetic membrane characteristics and the dispersion type of tenoxicam in the hydrogel base (dissolution or suspension) were the variables that affected the drugs diffusion, as the device and the experimental conditions have been kept constant throughout the test. Moreover, the sink conditions could be maintained throughout the test, since the TNX concentration in the established receptor medium (PBS pH 7.4 with 
$30 \%$ ethanol) after each sampling was at least 5 times lower than the solubility coefficient of drug in this medium.

The differences between the values of tenoxicam steady-state flux through the studied porous artificial membranes can be attributed to their different rate limiting ability. Thus, considering the values of this parameter obtained for GEL-TNXdiss formulation, all tested synthetic membranes behaved as high flux membranes (226.2-233.9 $\mu \mathrm{g} / \mathrm{cm}^{2} / \mathrm{h}$ ), except for the cellulose-based Millipore membrane, which produced a slightly lower flux $\left(216.9 \mu \mathrm{g} / \mathrm{cm}^{2} / \mathrm{h}\right)$, most likely because of its thickness (the thickest membrane of all). From the hydrogel containing dissolved TNX (dispersed at molecular level), the drug diffused easily through the synthetic membranes, more precisely through their pores filled with receptor medium (saline phosphate buffered $\mathrm{pH} 7.4$ with $30 \%$ ethanol) in which TNX is soluble. As a result, it can be suggested, that from the GEL-TNXdiss formulation the TNX diffusion through the synthetic membrane will be governed by the membrane characteristics, other factors, like the mechanical (rheological) properties of the vehicle having only a minor influence.

On the other hand, the approximately 2-fold lower TNX flux values produced by the GEL-TNXsusp formulation, cannot be attributed to the membrane characteristics, but to the dispersion type of tenoxicam in the hydrogel base. This assertion is supported by the generally accepted assumption that the diffusion of the suspended drug from a hydrogel through the synthetic membranes will mainly depend on the size of the suspended particles and their solubility, since the drug particles must dissolve first, so that its molecules can diffuse to the vehicle/synthetic membrane interface [10]. Under these conditions, it can be concluded that the physical properties of the synthetic membranes exerted only a secondary effect on the tenoxicam diffusion from the $G E L$ TNXsusp formulation, as indicated by the different values of the steady-state flux (Table II). Similar to the GEL-TNXdiss formulation, for the GELTNXsusp formulation the synthetic membranes Supor PES, Tuffryn PS and Millipore M.E.C. have behaved as high flux membranes (129.0-137.9 $\mu \mathrm{g} / \mathrm{cm}^{2} / \mathrm{h}$ ), while Teknokroma M.E.C. and Teknokroma PA membranes could be classified as low flux membranes $\left(114.2-116,9 \mu \mathrm{g} / \mathrm{cm}^{2} / \mathrm{h}\right)$.

Also, it can be observed that both high flux and low flux membranes showed similar diffusion profiles of tenoxicam for both formulations, GEL-TNXdiss and GEL-TNXsusp, which indicated a linear diffusion rate, with a slight gradient reduction after 4 or 6-7 hours, especially for Teknokroma M.E.C. and Teknokroma PA membranes. It is interesting to mention, that in the case of the hydrogel containing dissolved TNX, high flux membranes were mainly the polymeric membranes used for microfiltration, as well as the Teknokroma cellulose-based membrane, while a lower-flow membrane was the Millipore membrane cellulose, used for ultrafiltration. In the case of the hydrogel containing suspended TNX, the high flux membranes were the polymeric membranes Supor PES and Tuffryn PS, as well as the cellulose ester membrane Millipore, while the polymeric membrane Teknokroma PA and the cellulose-based membrane Teknokroma were low flux membranes.

Correlation of steady-state flux with membrane thickness

From Figure 2 it can be noted that there is no robust direct correlation between the flux of the transferred tenoxicam from the two hydrogels with the thickness of the tested membranes $\left(\mathrm{R}^{2}<0.99\right)$.
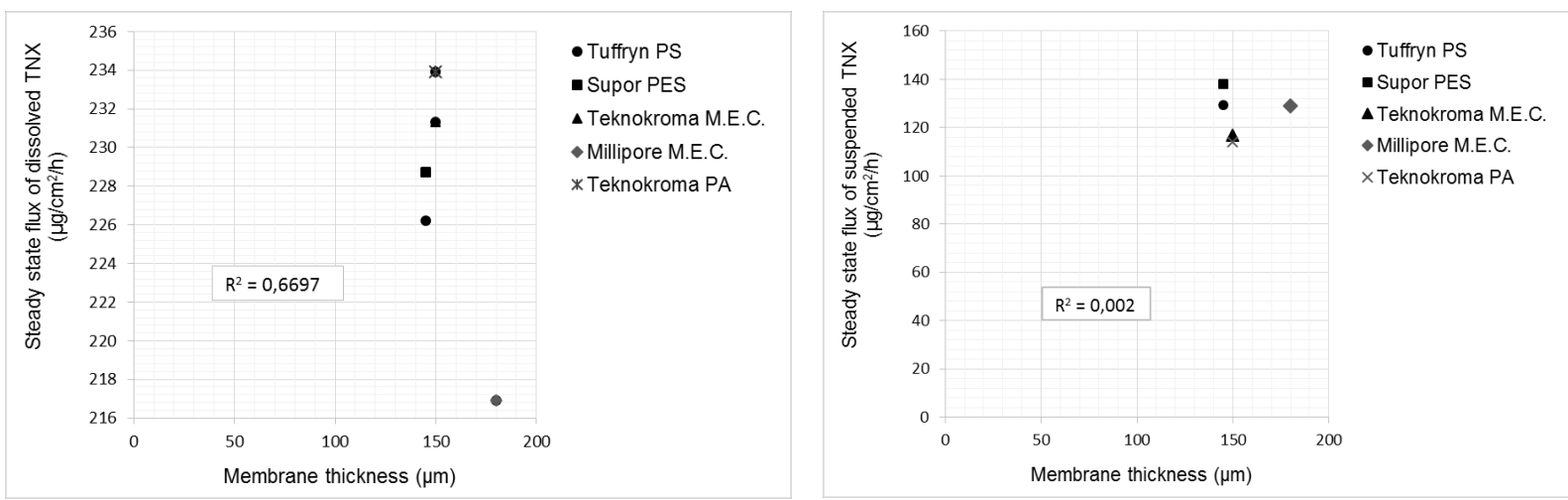

Figure 2

Correlation between the tenoxicam steady state flux and the thickness of tested artificial membrane

The correlation studies, performed in order to associate tenoxicam flux with membrane thickness, did not reveal a direct linear relationship, suggesting that drug flux may be affected by other characteristic membrane parameters, such as porosity and tortuosity. It can be observed that, 
FARMACIA, 2019, Vol. 67, 1

between the two synthetic membranes used for microfiltration, the Supor PES membrane produced a slightly higher flux value than that obtained for the Tuffryn PS membrane, although both have the same thickness $(145 \mu \mathrm{m})$ and the same pore size $(0.45 \mu \mathrm{m})$. The difference between the permeability of these two membranes for the dissolved or suspended tenoxicam can be attributed to another specific property, namely porosity. According to the manufacturer, the Tuffryn membrane has a lower porosity $(\varepsilon \sim 60 \%)$ than the Supor membrane $(\varepsilon \sim 80 \%)$, and the tenoxicam flux values were directly proportional to their porosity. Consequently, for these two membranes, their porosity can be considered the governing factor of the TNX diffusion process. In case of GELTNXdiss formulation, among the ultrafiltration membranes, the Teknokroma nylon and cellulose based membranes produced the highest flux values, although they showed a slightly bigger thickness than the polymer microfiltration membranes (150 $\mu \mathrm{m}$ versus $145 \mu \mathrm{m})$; in contrast, the flux value produced by the Millipore M.E.C membrane (with a $180 \mu \mathrm{m}$ thickness) was the lowest among the values obtained for dissolved TNX, but showed a high value in case of GEL-TNXsusp formulation. For this last formulation, the lowest amounts of TNX were transferred through the Teknokroma M.E.C. and Teknokroma PA membranes, although their thickness was only slightly bigger than that of the microfiltration polymeric membranes.

Considering these observations and the fact that all studied porous membranes had the same pore size $(0.45 \mu \mathrm{m})$, it can be suggested that along with the porosity and thickness, tortuosity had a significant influence on the flux of drug, as the research group of Hatanaka also observed [16]. In this study, a sligthly higher TNX transfer was observed from the GEL-TNXdiss formulation through Teknokroma M.E.C. and Teknokroma PA ultrafiltration membranes, than that through Supor PES and Tuffryn PE microfiltration membranes, although the first two membranes possess a bigger thickness $(150 \mu \mathrm{m})$ but the same pore size $(0.45 \mu \mathrm{m})$. This could indicate that the tortuosity and porosity of the two ultrafiltration membranes, influenced in a greater extent the TNX flux from the GEL-TNXdiss formulation, although the manufacturer does not provide data on their porosity and tortuosity.

\section{Conclusions}

The synthetic porous membranes tested with Franz cells showed different resistance to tenoxicam diffusion from HPMC-based hydrogel formulations. Based on the experimental results, one can conclude that for testing the performance of the tenoxicam containing hydrogels, the microfiltration membranes, with a porosity of over $60 \%$ and a maximal thickness of $150 \mu \mathrm{m}$, can be recommended as ideal. Further, in selecting the appropriate artificial membrane for the in vitro tenoxicam disponibility test other factors should be taken into account, such as the dispersed form of TNX in the vehicle (dissolved or suspended) related with drug thermodynamic activity, as well as the membrane compatibility with the components of the formulation and of the receptor medium. However, further studies testing the in vitro tenoxicam permeability of other synthetic membranes presently commercialized should be usefult for the performance evaluation of topical formulations containing tenoxicam.

\section{References}

1. Fan Q, Mitchnick M, Loxley A, The issues \& challenges involved in vitro release testing for semi-solid formulations. Drug Delivery Technology, 2007; 7(9): 62-66.

2. FDA-SUPAC-SS. Guidance for Industry. SUPAC-SS Non-sterile Semisolid Dosage Forms. Scale-up and Postapproval Changes: Chemistry, Manufacturing and Controls. In vitro Release Testing and In Vivo Bioequivalence Documentation 1997; pp. 19-24.

3. Garg R, Girotra P, Singh SK, Kumar D, Chakarvarti SK, Evaluation of Track Etch Membrane as a surrogate for ex-vivo drug permeation studies. Int J Pharm Sci Drug Res., 2014; 6(3): 189-192.

4. Haq A, Dorrani M, Goodyear B, Joshi V, Michniak-Kohn B, Membrane properties for permeability testing: Skin versus synthetic membranes. Int J Pharm., 2018; 539(1-2): 58-64.

5. Hatanaka $T$, Inuma $M$, Morimoto $Y$, Prediction of skin permeability of drugs. 1. Comparison with artificial membrane. Chem Pharm Bull., 1990; 38: 3452-3459.

6. Ghica MV, Albu Kaya MG, Dinu-Pîrvu CE, Lupuleasa D, Udeanu DI, Development, optimization and in vitro/in vivo characterization of collagen-dextran spongious wound dressings loaded with flufenamic acid. Molecules, 2017; 22(9): 1-22.

7. Miron DS, Rădulescu FS, Voicu VA, Lupuleasa D, Sacuiu I, Diffusional and rheological evaluations as valuable quality control and in vivo performance prognostic tools for topical drug products. Farmacia, 2010; 58(4): 485-493.

8. Ng SF, Rouse JJ, Sanderson FD, Eccleston GM, The relevance of polymeric synthetic membranes in topical formulation assessment and drug diffusion study. Arch Pharm Res., 2012; 35(4): 579-593.

9. Ng SF, Rouse JJ, Sanderson D, Eccleston GM, A comparative study of transmembrane diffusion and permeation of ibuprofen across synthetic membranes using Franz diffusion cells. Pharmaceutics, 2010; 2: 209-223.

10. Olejnik A Goscianska J, Nowak I, Active compounds release from semisolid dosage forms. $J$ Pharm Sci., 2012; 101(11): 4032-4045. 
11. Salamanca $\mathrm{CH}$, Barrera-Ocampo A, Lasso JC, Camacho N, Yarce CJ, Franz diffusion cell approach for pre-formulation characterisation of ketoprofen semi-solid dosage forms. Pharmaceutics, 2018; 10(3): 1-10.

12. Schaefer UF, Hansen S, Schneider M, Models for Skin Absorption and Skin Toxicity Testing. In Ehrhardt C, Kim KJ (eds.). Drug Absorption Studies In Situ, In Vitro and In Silico Models. New York: AAPS PRESS, Springer, 2008, 3-33.

13. Siewert M, Dressman J, Brown CK, Shah VP, FIP, AAPS, FIP/AAPS guidelines to dissolution/In vitro release testing of novel/special dosage forms. AAPS PharmSci Tech., 2003; 4(1): 43-52.

14. Todorescu CD, Dinu-Pirvu C, Ghica MV, Anuţa V, Popa DE, Vlaia L, Lupuleasa D, Influence of formulation variables on ketoprofen diffusion profiles from hydroalcoholic gels. Farmacia, 2016; 64(5): 728-735.

15. Uchida T, Kadhum WR, Kanai $\mathrm{S}$, Todo $\mathrm{H}$, Oshizaka T, Sugibayashi K, Prediction of skin permeation by chemical compounds using the artificial membrane, Strat-M ${ }^{\mathrm{TM}}$. Eur J Pharm Sci., 2015; 67: 113-118.

16. Ueda CT, Shah VP, Derdzinski K, Topical and transdermal drug products. Pharmacopeial Forum, 2009; 35: 750-764.

17. Yacobi A, Ueda CT, Shah VP, In Vitro product quality tests and product performance tests for topical and transdermal drug products. In Shah VP, Maibach HI, Jenner J (ed.). Topical Drug Biavailability, Bioequivalence and Penetration, second edition. New York: Springer. 2014; 81-90.

18. ***Semisolid Drug Products - Performance Tests. in The United States Pharmacopoeia and National Formulary USP38-NF 33. The United States Pharmacopoeial Convention, Inc.: Rockville, MD. $2015 ; 1625$.

19. $* * *$ Chemistry of Methocel ${ }^{\mathrm{TM}}$ Cellulose Ethers - A Technical Review. Dow Chemical Company. 2013, 14-15. 